\title{
Paparazzi v British media
}

In spite the tragedy of Princess Diana and the public backlash against paparazzi, the British Government has refused to implement recommendations of statutory control in 'privacy'. It must have faith in self-regulation by the media; and it does not believe control is necessary in a democracy.

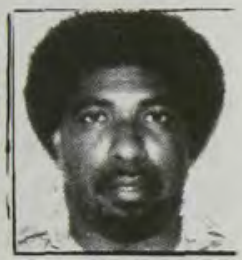

\section{By NASH G. SORARIBA}

THE PUBLIC supported the paparazzi and the European media to kill the late Diana, Princess of Wales. Diana once confided in a reporter and said that the press didn't know when enough was enough, and that she was always the target.

She was right. The press photographers, newspaper editors and the paparazzi didn't know when to stop. The same public who grieved over her death on 1 September 1997 purchased and read every gossip and picture that was printed - even after her death. So, here we are dealing with a world full of hypocrisy. The finger of guilt should not only be pointed at the tabloid press.

Writes Andrew Neil, editor-in-chief of The Scotsman, Scotland on Sunday and The European:

Europe has a problem. A renegade pose of photographers, known collectively as the paparazzi, has become a global wolfpack, stalking celebrities for cash. Their work is needlessly intrusive, often amounting to the collective stalking of public figures for no legitimate news purpose, and their behaviour can be barbarian: the first instinct of those who arrived at the scene of the car crash of Diana and Dodi was to take pictures rather than help save the couple. ${ }^{1}$

Diana once admitted that she felt raped by the prying eyes of the paparazzi: 'and I have to protect my sons, and that's what I'm going to do...'

The late Princess of Wales was not so much affected or intruded on by the official press (the newspaper photographers and the TV cameraman), because half the time she needed them to publicise those charitable causes she was involved in. It was the paparazzi, the amateurs and the freelancers, or those who 


\section{NASH SORARIBA}

stalked relentlessly and took pictures for the money that she felt raped by.

Roy Greenslade in his column 'The making of an icon', says the theory is that:

...she was a creature of newspapers and television, endlessly pictured and continuously lauded so that the public were coralled into adoring her. All the press then had to satisfy the public's appetite. ${ }^{2}$

Again we see an implication being drawn that the media alone did not make her into an icon. After the triumph comes the tragedy. As Greenslade points out, 'in a dénouement of Shakespearian proportions, she perished at the hands of those who had raised her up. Hounded by the press' mercenary army, the paparazzi.' In death, her fame was to be yet greater than in life. The late princess even sold more papers and magazines, and generated even higher television audience ratings.

In reality, the paparazzi would have no market for their dubious trade if editors of publications that sign up to codes of conduct that prohibit unjustifiable intrusion in their own countries did not buy and publish pictures from foreign paparazzi who have broken every rule in the book. Those editors in turn, would not dish out large sums for such photographs if the public did not rush out in their millions to buy the newspapers and magazines that print them.

There has been an emotional and reactionary chorus - with some British Parliamentarians calling for tougher privacy laws as it became obvious in the light of Diana's death. For over a week in London, men who took their long queues with floral tributes to pay their last respects spat and swore at news photographers, TV cameramen, against the background of public anger and calls for tougher privacy laws, Eamonn McCabe, picture editor of the Guardian defends the photographers at the scene of the crash in Paris.

Accepting the fact that if you can help at an accident scene, you do so taking pictures, how can you blame photographers for doing their jobs? (McCabe, Guardian, 8 September 1997, p 5)

'After Diana's car crashed, the chasing photographers were always going to be blamed for killing her. The car crashed and the photographers kept working. The story changed from a social picture to a huge news picture. It is hard to stop when the story changes suddenly. The adrenaline flows,' says McCabe.

However, McCabe fails to distinguish the news photographers from the hounding paparazzi, distorting the reputation of the journalism professivin which adheres to set ethical standards. His defence fails to justify the presence of the paparazzi and their actions. 

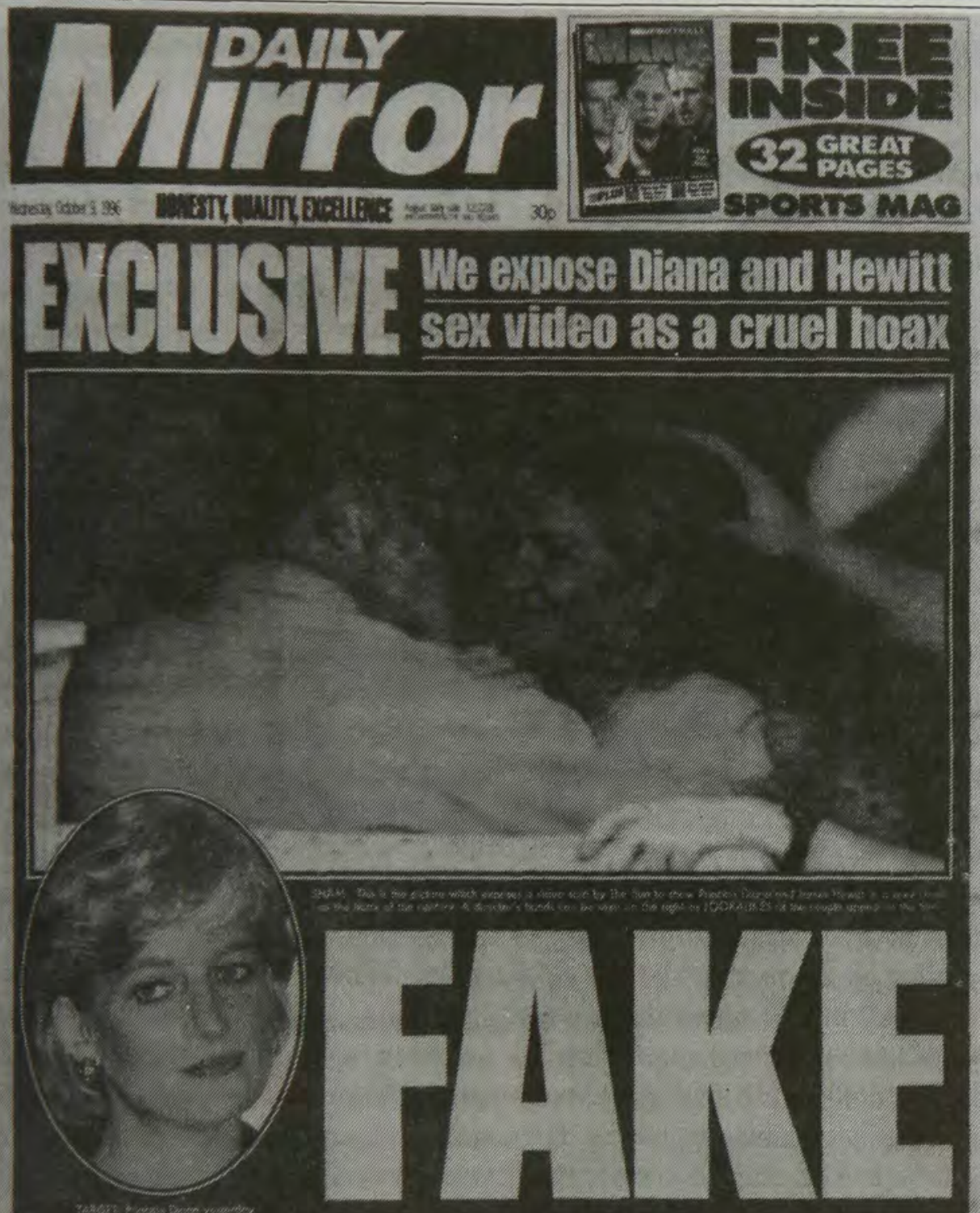

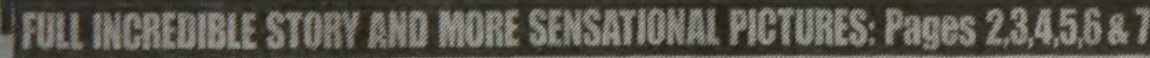

The Daily Mirror's 'fake video' Diana cover story on 9 October 1996.

The general mood of the public was adequately summed up by Earl Spencer on the morning of his sister's death.

However, I always believed that the press would kill her in the end. But not even I could imagine that they would have a direct hand in her death, as seems to be the case. It will appear that every proprietor and editor of every publication that has paid for intrusive and exploitative photographs 


\section{NASH SORARIBA}

of her, encouraging greedy and ruthless individuals to risk everything in pursuit of Diana's image, has blood on his hands today. (Earl Spencer's statement: BBC 2, 1 September 1997)

As for the British press, one could argue that the failure to implement the Calcutt Committee (1990) proposals on privacy and the Government's rejection of any statutory intervention, preferring to rely on industry self-regulation has given rise to the English law providing no effective remedy from gross intrusions into peoples' personal life by the media.

However, under the English Law, the criminal and civil laws do impose restrictions upon news gathering and publications under other rights and remedies.

Generally, it can be argued that the media in the United Kingdom is free to gather and publish information so far as it is not restrained by the criminal law or civil law, given the nature of its democratic environment with a tradition of a right to free speech and other basic freedoms.

This does not mean that the media is totally free to take advantage of the members of the public, organisations or newsmakers generally, to intrude by whatever means and publish their personal or private lives/property in the name of selling their news. Mass media (eg: newspapers, radio and television) must be seen to act with responsibility and great restraint, thus adhering to agreed codes of conduct.

If the Government refused to implement recommendations of statutory control in areas such as 'privacy', by implication, it must have faith in selfregulation by the media; and secondly it does not believe that statutory control is necessary in a democratic society.

Unfortunately, self-regulation has not been very effective. On the other hand, it is not a question of the Government's 'failure to implement the Calcutt Committee proposals on privacy' laws, rather it is arguable, given the nature of state laws and practice to ask whether it was reasonably justifiable or necessary in a democratic society like the United Kingdom to introduce such laws.

Those in the legal profession and the media felt that if a statutory provision was made to that effect, the law may unnecessarily protect those who do not deserve protection. Such laws if made, must not be seen to conflict with the exercise of other rights.

Although the English law does not provide a direct right of privacy ${ }^{3}$, other rights and remedies which provide restrictions to the media include the laws regulating defamation, criminal libel, trespass and harassment, nuisance, malicious falsehood, breach of confidence, copyright and others. 


\section{Definition}

Consequently, under the code of practice upheld by the Press Complaints Commission (PCC), supported by the newspaper and magazine industry, it covered many of the same area covered by broadcasters' guidelines ${ }^{4}$, although these guidelines are not strictly included as legal codes governing the content of broadcast program services. The PCC has a separate clause dealing with aspects of privacy - harassment, intrusion into grief or shock, misrepresentation, innocent relatives or friends, children in sex cases, victims of crime, discrimination, hospitals, listening devices and confidential sources.

Privacy is defined as: 'intrusions and inquiries into an individual's private life without his or her consent, including the use of long-lens photography, to take pictures of people on private property without their consent are not generally acceptable and publication can only be justified when in the public interest'. [Courtney, C., et al (1995) p 310]

Private property is defined as: (i) any private residence, together with its garden and outbuildings, but excluding any adjacent fields or park land and the surrounding parts of the property within the unaided view of passers-by, (ii) hotel bedrooms [but not other areas in a hotel] and (iii) those parts of a hospital or a nursing home where patients are treated or accommodated]. ${ }^{5}$

The Younger Committee [1972] discussed the concept of privacy and the various attempts to define it since Judge Cooley's formulation of 1888 , 'the right to be let alone'. ${ }^{6}$ This definition was adopted by Warren and Brandeis in their seminal article: 'The Right to Privacy', in the Harvard Law Review of 1890 and by later authorities. ${ }^{7}$ But described by the Calcutt Committee in 1990 as too simplistic. Although the Calcutt Committee looked at the privacy laws of several other common law countries, they could not identify a satisfactory definition under any statute. Countries like France, Germany and the United States law were developed through case by case basis.

The committee however, provided a working definition as a yardstick.

3.5 Privacy could be regarded as the antithesis of what is public: hence, everything concerning an individual's home, family, religion, sexuality, personal legal and personal financial affairs. ${ }^{8}$

3.7 'For working purposes we have adopted a formulation of privacy similar to that in paragraph 3.2.' Our formulation is:

the right of the individual to be protected against intrusion into his personal life or affairs, or those of his family, by direct physical means or by publication of information. We discuss in paragraph 3.12 the extent to which this right needs to be offset against other rights.

3.8 A right to privacy could include protection from:

(a) physical intrusion; 


\section{NASH SORARIBA}

(b) publication of hurtful or embarrassing personal material (whether true or false);

(c) publication of inaccurate or misleading personal material; and

(d) publication of photographs or recordings of the individual taken without consent. ${ }^{10}$

\section{Background}

The Calcutt report is the fourth and the latest in a long line of inquiries undertaken since after the Second World War. Over the years, various committees have investigated questions relating to press regulation and privacy. ${ }^{11}$ Three of which were royal commissions concerning the press and one was an inquiry on privacy which was reported in 1972 . The most recent inquiries on privacy (Privacy and Related Matters) was headed by Sir David Calcutt,QC. which reported to the Home Secretary in 1990.

The Privacy Committee was established in response to widespread concern in the late 1980s about press abuses, particularly those perpetrated by some tabloid newspapers. ${ }^{12}$

The concern reportedly reached such a pitch that several MPs came up with Private Member's Bills during the 1987-89 sessions, the Government was not willing to support such proposed legislation because of its long-standing reluctance to institute statutory control of the press. In 1989, the Government announced the setting up of the 'Committee.'13

When the Committee reported in 1990 with a series of important recommendations, it set out the groundwork for debate on press regulation and privacy over the preceding years. In its recommendation the Committee pointed out that the Government should allow the press to prove that self-regulation could work under a new Press Complaints Commission (PCC), and that after a given period if the media industry failed to set up the commission, or if the new Commission failed to show effectiveness on self-regulation; then statutory measures be the answer. The Committee also recommended the introduction of criminal offences to outlaw the most blatant forms of intrusion into privacy for publication purposes, together with further legal restrictions on press reporting'. ${ }^{14}$

The Press Complaints Commission (PCC) was set up on 1 January 1991. After the 18-month probationary period, Sir David Calcutt was requested by the Secretary of State for National Heritage to review and assess the effectiveness of non statutory self-regulation under the PCC; and to consider whether any further measures would be needed to deal with intrusions into personal privacy by the press, and to make recommendations.

\section{The Press Complaints Commission (PCC)}

Prior to the establishment of the PCC, the newspaper industry set up the 126 PACIFIC JOURNALISM REVIEW 4:1 1097 
Press Standards Board of Finance Limited (Pressbof), whose functions was to raise money and finance the new Press Complaints Commission.

When the PCC came into operation it was entrusted with the task to adjudicate on complaints alleging breaches of a Code of Practice drawn up by a committee of editors, convened by Pressbof. The code dealt with six subjects: accuracy and fairness, privacy, cheque book journalism, race reporting, financial journalism, and disclosure of sources. Unjustified infringement of privacy is prohibited by various ethical codes as well as by the PCC Code. Clauses 4 (Privacy), 6 (Misrepresentation) and 7 (Harassment) of the Code, framed by the newspaper and periodical industry, sets out the general rule against press incursion into personal privacy unless there is a legitimate public interest in the story.

4. Intrusions and enquiries into an individual's private life without his or her consent are not generally acceptable and publication can only be justified when in the public interest. This would include:

(i) Detecting or exposing crime or serious misdemeanour.

(ii) Detecting or exposing seriously anti-social conduct.

(iii) Protecting public health and safety.

(iv) Preventing the public being misled by some statement or action of an individual or organisation. ${ }^{15}$

However, the justification for invasion of privacy should be based on more specific grounds than the 'public interest'. According to Robertson and Nicol [1992, p.532] 'it cannot be contended that press revelation of adultery or homosexuality or run-of-the-mill heterosexual behaviour amounts to the exposure of serious anti-social conduct, unless attended by circumstances of gross hypocrisy.' 16

Most of these rules adopted by the PCC were largely drafted by Calcutt and cunningly revised and incorporated by the press to suit their needs, even to the extent of breaching one or two of the clause which could easily be excused under the meaning of others.

Such phrases as 'serious misdemeanour' are found to lack clarity. Another phrase which could legitimise a certain degree of excuse which the press can use to justify their actions is - 'seriously anti-social conduct', or 'preventing the public from being misled by some statement or action of that individual.' ${ }^{17}$ These phrases in practice, constitute invasion of privacy, because the only way to get at the story would be a thorough investigation into the affairs of religious leaders or politicians.

Under the code of the PCC, what constitutes 'intrusion' can be censored if it amounts to 'subterfuge or harassment', or if it constitutes extreme forms of 


\section{NASH SORARIBA}

privacy invasion condemned by Clauses 5 (Hospitals) and 9 (Intrusions into grief or shock). ${ }^{18}$ However, this code applying to the conduct of print journalists, cannot be enforced by legal sanctions. On the other hand, the broadcasters face 'legal sanctions' if they are found infringing various codes.' ${ }^{19}$

\section{Calcutt Committee (1990) report}

The Committee on Privacy and Related Matters (Cm 1102) reported back to the Government in June 1990. This report, also known as Calcutt 1, provided a formula for statutory intervention which was endorsed by both sides of the House of Commons.

Firstly, 'if the press fails to demonstrate that non-statutory self-regulation can work effectively, a statutory system for handling complaints should be introduced.' [Courtney et al (1995) p 20] Secondly, 'if maverick publications persistently decline to respect the authority of the PCC, the commission should be placed on a statutory footing. It should be given sufficient statutory powers to enable it to require any newspaper, periodical or magazine to respond to its inquiries about complaints and to publish its adjudications as directed. It should be able to recommend the payment of compensation.' [ibid.]

Thirdly, 'should it at any time become clear that the reformed non-statutory mechanism is failing to perform adequately, this should be replaced by a statutory tribunal with statutory powers, implementing a statutory code of practice, and with power to award compensation. Two 'triggers' for this process would be failure to comply with the PCC's rulings or the flouting of its code.' [ibid.]

And finally, 'in privacy cases, the Press Complaints Tribunal should be able to restrain publication of material in breach of the code of practice by means of injunctions.' ${ }^{21}$ The Calcutt Committee further proposed the creation of three privacy offences applying only to journalists. These were [Courtney et al 1995, p 22]:

(i) entering private property, without the consent of the lawful occupant, with intent to obtain personal information with a view to publication;

(ii) placing a surveillance device on private property, without the consent of the lawful occupant, with intent to obtain personal information with a view to publication;

(iii) taking a photograph, or recording the voice, of an individual who is on private property, without his consent, with a view to its publication with intent that the individual shall be identifiable. [see also The Government's Response (1995), p 10]

However, it would be a defence to show that the above breaches had been committed: 
(i) for the purpose of preventing, detecting or exposing a crime, or other seriously anti-social conduct; or

(ii) for the purpose of preventing the public from being misled by some public statement or action of the individual concerned; or

(iii) for the purpose of informing the public about matters directly affecting the discharge of any public function of the individual concerned; or

(iv) for the protection of public health or safety;

(v) under any lawful authority. ${ }^{22}$

In July 1992, at the end of the probationary period for the PCC, the government again asked Sir David Calcutt to carry out an assessment on how self-regulation had worked since the committee's report. By January 1993, he reported back through his Review of Press Self-Regulation (published in January 14, 1993 (Cm 2135 ) carried out in 1992 , that the press had not done what he had expected. Sir David concluded that self-regulation had not been effective, and recommended that the Government should 'introduce a statutory complaints tribunal'.

He made five other recommendations bearing on intrusions into privacy by the press. One of them was that the criminal offence proposed by the Privacy Committee to deal with specific forms of physical intrusion should, with modifications, be enacted. In 1993, two other documents were released, apart from Sir David's Review of Press Self-Regulation. ${ }^{23}$

In March 1993, the National Heritage Select Committee published a report on Privacy and Media Intrusion (Cm 2918); while a consultation paper was released by the Lord Chancellor and the Secretary of State for Scotland, titled: Infringement of Privacy, (published on 30 July 1993). The latter suggested that there should be a new statutory instrument protecting the right to privacy instead of relying on uncertainties within the common law. ${ }^{24}$

Areas of privacy under the proposal included matters concerning personal health, personal communications, family and personal relationships, a right to be free from harassment and molestation. Defences should be consent, lawful authority, absolute or qualified privilege and public interest. ${ }^{25}$ Suggested remedies were damages - especially for mental distress, which might include aggravated damages but no exemplary damages. And the awards to be normally below $£ 10,000$. [Milmo, QC, 1993 - NLJ: p.1182]

The National Heritage Select Committee on the other hand recommended the introduction of a Protection of Privacy Bill and a number of criminal offences resulting from unauthorised use of invasive technology and harassment. The committee suggested that a statutory press complaints tribunal should not be established, but that voluntary regulation would be strengthened by a five-tier structure of responsibility. This would involve: 


\section{NASH SORARIBA}

- Editors' contracts of employment requiring them to enforce the industry's Code of Practice;

- The appointment by individual newspapers of independent readers' representatives;

- The replacement of the PCC by a press commission charged specifically with upholding press freedom and with the power to order corrections and apologies, to award compensation and impose fines;

- The appointment of a statutory press ombudsman;

- The ombudsman having power to seek a High Court order in the event of a newspaper refusing to pay a fine or compensation. ${ }^{26}$

Another recommendation was for the Government to consider introducing a civil remedy for infringement of privacy.

\section{The Government's view}

The Government was reluctant to introduce any form of legislation. Its response to the Fourth Report of the National Heritage Select Committee, on Privacy and Media Intrusion ${ }^{27}$ (HMSO Ref. 294-1), the Lord Chancellor's consultation paper and Sir David's Review; the Government published a White paper: Privacy and Media Intrusion (Cm 2918) on 17 July, 1995. The main thrust of which was contained in the following:

A free press is vital to a free country. Many would think the imposition of statutory controls on newspapers invidious because it might open the way for regulating content, thereby laying the Government open to charges of press censorship. Furthermore, the Government does not believe that it would be right in this field to delegate decisions about when a statutory remedy should be granted to a regulator such as a tribunal. For both these reasons, the Government does not find the case for statutory measures in this area compelling. It believes that, in principle, industry self-regulation is much to be preferred. That conclusion applies equally to Sir David Calcutt's statutory complaints tribunal and to the National Heritage Select Committee's statutory Press Ombudsman proposal. ${ }^{28}$

The Government further stated that there was no persuasive case for statutory regulation of the press, saying it did not see the need to introduce the statutory press tribunal, recommended by Sir David Calcutt. And as its final view, the concept of a statutory Press Ombudsman was also rejected. In response to the Calcutt proposal for the creation of three new criminal offences applying 'only to journalists', the Government indicated that there was no immediate plan to legislate in this area.

It made its stance clear saying, it had no plans to introduce a new tort 
regarding the infringement of privacy, firstly because: if a tort was formulated, it would be seen as a significant development of the law and that they were not convinced that a sufficient case had been made for such a law to be introduced. Secondly, the Government strongly preferred the principle of self-regulation.

In relation to self-regulation by the Press Complaints Commission, the Government asked the newspaper industry to consider a number of improvements including:

- The introduction of a lay element into membership of the Code Committee;

- The introduction of a hotline whereby the PCC or its Privacy Commissioner might warn editors, thought to be likely to publish material obtained in breach of the Code, of the consequences of doing so;

- The adoption of performance targets, publication of fuller adjudication summaries and greater use of oral hearings;

- The setting up by the industry of a compensation fund;

- The introduction of a number of amendments to the Code, in particular

to place greater weight on the protection of individual privacy.

As the Government strongly favoured the self-regulatory mechanism as opposed to legislative framework, expectations are that the media industry needs to make further improvements based on the Government's recommendations.

\section{The English Legal system}

Just as there is no positive right to freedom of expression in the English Law, there is no right to privacy either. Those whose rights or right to privacy is invaded have no remedy, unless a specific crime or tort has been committed. Concerns over the intrusion of privacy by the media reporting still provokes debate about whether a right to privacy ought to be put into law. After a series of stories about the private lives of royalty, politicians and others, for example the case of Kaye $v$ Robertson (1991) clearly showed how far some newspapers would go to get their story.

The actor Gordon Kaye had been involved in a serious car accident, and was recovering from surgery in hospital. A newspaper photographer managed to sneak into Kaye's hospital room, and photographs of Kaye in his hospital bed, taken without his consent, were then published in the newspaper. The Court of Appeal granted an injunction on the basis of a malicious falsehood, but affirmed that there was no general right to privacy in English law. 29

The court granted an injunction, stopping the newspaper from publishing the photographs. When the case came to court, Lord Justice Bingham, one of the judges, said: 


\section{NASH SORARIBA}

The defendants' conduct towards the plaintiff was a monstrous invasion of his privacy ...If ever a person has a right to be let alone by strangers with no public interest to pursue, it must surely be when he lies in hospital recovering from brain surgery and in no more than partial command of his faculties. ${ }^{30}$

However, such rulings cannot be taken for granted because newspaper publishers, commercial radio stations and TV stations are running a business and they can publish the offending article or pictures before being detected or stopped. Information nowadays is regarded as a property - something of commercial value, which can be bought and sold. ${ }^{31}$

On the other hand, terms like 'tabloid journalism' or 'cheque book journalism' are common because certain classes of information or those which are deemed secret or exclusively new and sensitive (scoop), and that can help sell the papers have a high commercial value. Hence, information can be injuncted, embargoed - irrespective of its significance, regardless of political debate or current public policy.

Therefore, the laws which allow injunctions and damages for breach of confidence and copyright are powerful weapons against 'media use of information supplied by moles, whistle blowers and others who leak secrets from within organisations. ${ }^{32}$

Whenever a plaintiff takes out a court injunction to stop a publication on the grounds of confidence, it is simply a claim over a right to protect privacy or private property. Quite often the media or those who defend the media resort to the argument about the 'public interest' or that certain information needs to be disclosed because it is in the public interest. The courts on the other hand have established that not everything of interest to the public is in the public interest: 'there is a distinction between stories that appeal merely to prurient or morbid curiosity and those that contribute new and useful information to public debate. [Robertson and Nicol (1992), pp.172-173].

There is no law preventing the placing of a concealed transmitter (bug) or recorder on private property, but there are laws against trespass and breach of confidence. Likewise there is no law on privacy to prevent the interception of mobile phone messages, except in the circumstances outlawed by the Wireless Telegraphy Act 1949, or a breach of confidence. Neither does the law catch the tapping of landline phones, except in the circumstances outlawed by the Interception of Telecommunications Act of 1985 , or a breach of confidence.

\section{Some examples of past cases}

Journalists in the United Kingdom have little to fear when it comes to answering to charges of infringement of personal privacy. The Duchess of York had no 132 PACIFIC JOURNALISM REVIEW 4:1 1997 
remedy against the British newspapers that published pictures of her topless in France when on a holiday. But she won damages for infringement of privacy against a French newspaper in a French court because France has a law on privacy. The photographs were taken with a long-range camera. In the UK, 'a photographer can lawfully take a picture of anyone and a newspaper can print it without getting permission, however embarrassing that may be to the person concerned.' ${ }^{33}$

In 1992, a recorded conversation between the Prince of Wales and a married woman, Camilla Parker Bowles (the Camilla tapes), revealed that the two were intimate, but there was no evidence that wireless apparatus had been used 'with intent' to obtain information, ${ }^{34}$ as the law specifically stated.

David Mellor, the then National Heritage Secretary, had no remedy when his private conversations with an actress, Antonia de Sancha, were recorded and published. ${ }^{35}$

Tabloid newspapers are known for their sensational reporting and the use of photographs. Photographs can even be distorted to give false impression in order for the newspapers to enhance sales.

As Harold Evans, former editor of The Times and The Sunday Times and now president of Random House Publishing, explains: 'The camera cannot lie, but it can be an accessory to untruths. ${ }^{36}$ Such a situation is damaging especially to public figures, because newspapers can write 50 different captions for one photograph - each giving different meanings.

On 8 October 1996, The Sun printed eight partly distorted picture frames taken from video footage and below it splashed in bold white: DI SPY VIDEO SCANDAL, and in smaller print: 'She's filmed in bra and pants romp with Hewitt'. Beside the usual masthead was the picture of Princess Diana's face and next to it were the words: SUN ROYAL WORLD EXCLUSIVE.

The following day the Daily Mirror ${ }^{37}$ disclaimed the story as 'a cruel hoax' on its front page, and equally labelled it exclusive. 'We expose Diana and Hewitt sex video as a cruel hoax'. It was later discovered that the characters in the video were lookalikes and the Sun editor apologised, but the damage had been done.

The Sun admitted it had been conned by people who were out to make money from tabloid newspapers. Again the editor should have used his better judgement rather than being deceived into breaching his own code against cheque book journalism. The paper left itself open to possible payment of damages to Princess Diana and Major Hewitt.

Recently, an article in one of the tabloids titled MIRROR IN PHOTO PLEDGE TO DIANA, stated that the newspaper promised not to buy paparazzi pictures of Princess Diana after she defended her street scuffle with a photographer. ${ }^{38}$ 


\section{NASH SORARIBA}

She claimed she was the victim of a 'distressing intrusion' into her private life, and hoped the new anti-stalking law would protect her. Such an undertaking by a newspaper can best be described as being honest and responsible, while recognising the fact that such individuals are entitled to personal privacy.

\section{Other laws protecting privacy}

The United Kingdom has never incorporated the European Convention into domestic law, however, the courts do have regard for the Convention 'as persuasive assistance in case of ambiguity or doubt. ${ }^{39}$ The right to freedom of expression (Article 10$)^{40}$ has to co-exist with the right to privacy set out in Article 8:

1. Everyone has the right to respect for his private and family life, his home and his correspondence.

2. There shall be no interference by a public authority with the exercise of this right except such as is in accordance with the law and is necessary in a democratic society in the interests of national security, public safety or the economic well-being of the country, for the prevention of disorder or crime, for the protection of health or morals, or for the protection of the rights and freedoms of others.

Journalists in the UK are opposed to the idea of statutory protection of individual privacy because they believe that laws intended to protect the 'privacy' of individuals would in fact be used to prevent the media from revealing matters in the public interest, such as the misdeeds of wealthy and powerful people.

Although there are no specific laws protecting privacy, a number of laws may give limited protection. These include laws on trespass and harassment, defamation, criminal libel, breach of confidence, copyright, laws regulating press reports of court proceedings, the Wireless Telegraphy Act of 1949, the Interception of Communications Act 1985, and the Data Protection Act of 1984.

Under the Data Protection Act of 1984 , there is a right of privacy for the vast amount of information held about people on computer. The Act made it an offence for a data holder to disclose data to someone not entitled to receive it, but there were no specific criminal offence for people receiving the information until 1994. (McNae1995, p 277)

The Criminal Justice and Public Order Act 1994 created three new offences that might affect the work of journalists. 'They were procuring the disclosure of data covered by the 1984 Act, knowing or believing this to contravene the Act; selling the data; or offering to sell the data or information extracted from it' ${ }^{41}$

\section{Laws in other democracies}

134 PACIFIC JOURNALISM REVIEW 4:1 1007 
In March 1993, Article 19 published a report titled PRESS LAW AND MEDIA PRACTICE, which provided comparative data on press laws in eleven selected democracies. The study was meant to show how these countries balance the rights to press freedom and access to information against other social and individual interests. The seven civil law countries: Austria, France, Germany, Netherlands, Norway, Spain and Sweden represent different traditions and approaches to the question of press freedom; however, they reflect certain similarities as well as variations. ${ }^{42}$

The power of the courts and the increasing role of case law in Austria, France, Germany and Spain are analysed in this report. Netherlands, Norway and Sweden are respected for their voluntary press council systems. The common law countries like Australia, Canada, the United States and the United Kingdom offer distinctive features. However, the US offers some of the most extensively reasoned judgments in support of strong constitutional protections [Press Law and Practice, 1993, p vii, ].

Australia and the United Kingdom are the only two countries found to lack a written constitutional protection of freedom of expression. As in the UK, Australia has no general tort of privacy. France, Austria, Germany, Netherlands, Norway and Spain on the other hand, have privacy laws.

\section{Conclusion}

Despite the trust in the self-regulating mechanism, it does not seem to work. Therefore it is time for the Government to consider statutory intervention. But it is now common knowledge that legislation is just a blunt and ineffective instrument. And the main aim for the changes must seriously address the actions and the dubious trade of the paparazzi. France has the toughest privacy laws in Europe but that didn't stop the princess of Wales from getting killed there.

The paparazzi are slowly forging a global market, therefore the concern needs to be addressed internationally. The proprietors and their editors need to collectively observe and uphold a set standard - in order to discourage the growth of paparazzi market.

The call for privacy laws intensified in the late 1980s because of the increased number of incidents of intrusion into people's lives, mostly stories relating to the royal family. If the media shows keen interest in holding those in public offices to be accountable, it must be prepared to exercise responsibility and show accountability in its trade.

Even with the existence of the Press Complaints Commission, intrusive stories about the royal family and some public figures continue to be published. This has raised 'serious questions about the influence of the PCC and its ability 


\section{NASH SORARIBA}

to control the excesses of the press when the PCC is without any powers of sanction against offending members'. ${ }^{43}$

Basing on argument on the premises advanced by the members of the Law Society, if it is difficult to accommodate a general law on privacy within the existing body of the English law, then incorporation of the European Convention on Human Rights and Individual Freedoms into the common law of England and Wales should be the answer.

However, if the introduction or amalgamation of these articles into common law of England and Wales would have ramifications for areas other than the press, consideration should be given to the idea of specific offences recommended by the Calcutt Committee.

\section{References:}

Article 19 (1993). Press Law and Practice: A comparative study of press freedom in European and other democracies, London.

Blundy, A. (1994). 'Image makers', in The Guardian, February 2, p 13.

Courtney, C., Newell, D., and Rasaiah, S. (1995). The Law of Journalism. London: Butterworths.

Daily Mirror (1996), October 9, p 1.

Daily Mirror (1997), April 2, p 5.

Elliot, C. and Quinn, F. (1996). 'A right to privacy?' in English Legal System. London, Longman.

Milmo, Patrick, QC (1993). 'The new law of privacy', in New Law Journal, August 13.

Privacy and Media Intrusion: The Government's Response (1995), Department of National Heritage, London: HMSO Centre.

Report of the Committee on Privacy and Related Matters, (Sir David Calcutt, QC) June 1990.

Robertson, G. and Nicol, A. (3rd edition 1992).The Press Complaint Commission in Media Law. London: Penguin Books.

The Law Society (1992). Evidence to Sir David Calcutt Review of Press SelfRegulation.

The Sun, 8 October 1996, p 1.

Welsh, T. and Greenwood, W. (1995). 'Privacy', in McNae's Essential Law for Journalists. London: Butterworths.

\section{Notes:}

I 'World full of hypocrisy' in Media Guardian, 8 September 1997, p 4.

2 'The Making of an icon', Media Guardian, 8 September 1997, p 4.

${ }^{3}$ Courtney, et al (1995). p 296: It can be argued that the British law is in breach of its obligations under the European Convention on Human Rights (ECHR), by not considering Articles 8 and 10 of ECHR as a persuasive authority or in cases where statutory ambiguity and doubt exist.

136 PACIFIC JOURNALISM REVIEW 4: $: 1997$ 
${ }^{4}$ Robertson and Nicol (1992). pp 547-552, Broadcasting Complaints Commission (BBC) Act 1981 [re-enacted $1990 \mathrm{Act}$ ]: Under Section 54(1), its function is to investigate and adjudicate upon complaints of: (also p.606)

- unjust and unfair treatment in programmes.

- unwarranted infringement of privacy in programmes or in connection with their preparation.

${ }^{5}$ Courtney, C., et al (1995), p 310.

${ }^{6}$ Report of the Committee on Privacy and Related Matters (Sir David Calcutt [QC] Committee) June 1990, p 6.

7 Ibid.

\& Ibid.

9 Calcutt Committee Report (1990), Chapter 3 - General Principles:

3.2 The Younger Committee view was reiterated by most of our witnesses who addressed this issue. For example, the legal adviser to Express Newspapers (Mr Justin Walford) argued ( $\mathrm{p} 6$ ):

We do not believe that the right of privacy is capable of exact or satisfactory legal definition. Insofar as it is capable of general definition, we define it as the right of an individual to protection against unwarranted intrussion into, by direct physical means or by publication of information about, that person's private life or affairs, or the private life or affairs of their family.

${ }^{10}$ Op. Cit., p.7

"Privacy and Media Intrusion: The Government's response (1995), p 1.

12 Ibid.

${ }^{13}$ Privacy Committee.

${ }^{14}$ Privacy and Media Intrusion, p 2.

${ }^{15}$ Robertson and Nicol (1992) p 531.

${ }^{16}$ Ibid., p 532.

${ }^{17}$ Ibid.

${ }^{18}$ Ibid., p 533.

5. Hospitals

(i) Journalists or photographers making enquiries at hospitals or similar institutions should identify themselves to a responsible official and obtain permission before entering non-public areas.

(ii) The restrictions on intruding into privacy are particularly relevant to enquiries about individuals in hospital or similar institutions.

9. Intrusions into grief or shock

In cases involving personal grief or shock, enquiries should be carried out and approaches made with sympathy and discretion.

${ }^{19}$ Welsh and Greenwood (1995), p 267.

${ }^{20}$ Privacy and Media Intrusion, p 1.

2i Courtney, et al (1995), p-20

12 Privacy and Media Intrusion, p10.

${ }^{23}$ This review was a follow-up from the 1990 Home Office Report of the Committee 


\section{NASH SORARIBA}

on Privacy and Related Matters (Cm 1102), of which Sir David himself had been the chairman.

${ }^{24}$ The Lord Chancellor and Scottish office - Consultation paper, Privacy and Media Intrusion; $\mathrm{p} 36$.

${ }^{25}$ Milmo, Patrick, QC (1993). 'The new law of privacy', in New Law Journal, August 13, pp1182-1183.

${ }^{26}$ Ibid., 'Privacy and Media Intrusion', p 21

27 'The Fourth Report of the National Heritage Select Committee, on Privacy and Media Intrusion' (HMSO Ref. 294-1), published on 24 March1993.

${ }^{28}$ Privacy and Media Intrusion, p 4-5.

${ }^{29}$ Elliott and Quinn (1996), p 399.

30) Welsh and Greenwood (1995), p 267.

3) Robertson and Nicol (1992), p 172.

${ }^{32}$ Ibid.

${ }^{33}$ Welsh and Greenwood (1995), p 266.

${ }^{34}$ Ibid.

${ }^{35}$ Ibid.

${ }^{36}$ Blundy, A (1994). 'Image makers', in The Guardian, 2 February 1994, p 13.

${ }^{37}$ Daily Mirror, 9 October 1996, p 1.

${ }^{38}$ Daily Mirror, 2 April 1997, p 5.

${ }^{39}$ Courtney, et al (1995), pp 30-32.

t) Article 10 safeguards the right to freedom of expression:

1. Everyone has the right to freedom of expression. This right shall include freedom to hold opinions and to receive and impart information and ideas without interference by public authority and regardless of frontiers. This Article shall not prevent States from requiring the licensing of broadcasting, television or cinema enterprises.

2. The exercise of these freedoms, since it carries with it duties and responsibilities, may be subject to such formalities, conditions, restrictions or penalties as prescribed by law and are necessary in a democratic society, in the interests of national security, territorial integrity or public safety, for the prevention of disorder or crime, for the protection of health or morals, for the protection of the reputation or rights of others, for preventing the disclosure of information received in confidence, or for maintaining the authority and impartiality of the judiciary.

${ }^{41}$ Welsh and Greenwood (1995), p 277.

${ }^{42}$ Article 19 (1993), Press Law and Practice, p vii.

${ }^{43}$ The Law Society (1992), Evidence to Sir David Calcutt's Review of Press SelfRegulation, p 2.

Nash G. Sorariba is Lecturer in Journalism (Broadcast) at the University of Papua New Guinea. This is a revised version of a paper he prepared while on Master of Arts in Journalism studies at the Centre for Journalism Studies, University of Cardiff. 